\title{
Obtention chez l'échalote (Allium cepa L var aggregatum) de plantes haploïdes gynogénétiques par culture in vitro de boutons floraux
}

\author{
J Cohat \\ INRA, station d'amélioration de la pomme de terre et des plantes à bulbes, Kéraiber, F29260 Ploudaniel, France
}

(Reçu le 11 janvier 1994 ; accepté le 17 juin 1994)

\begin{abstract}
Résumé - Des embryons d'origine gynogénétique ont été obtenus par culture in vitro de boutons floraux de plusieurs génotypes d'échalote sur milieu B5 de Gamborg riche en sucre et contenant de l'acide 2,4-dichlorophénoxyacétique et de la 6-benzylaminopurine. La production d'embryons a débuté une cinquantaine de jours après la mise en culture et a été maximale entre le $82^{\mathrm{e}}$ jour et le $116^{\mathrm{e}}$ jour. Les cultures de boutons floraux entiers et d'ovaires isolés ont donné des résultats équivalents. Le stade d'évolution des boutons vers l'anthèse a peu influencé le résultat, de même que le repiquage des fleurs sur un milieu identique une quarantaine de jours après la mise en culture. Un fort effet génotype sous les conditions expérimentales utilisées a été mis en évidence, le nombre d'embryons formés par 100 fleurs implantées variant de 0 à 55 . Ce résultat est nettement supérieur aux meilleurs résultats obtenus chez l'oignon jusqu'à présent. Le pourcentage de plantes haploïdes parmi les plantes survivantes, 22 mois après le début de l'essai, était de 77,6 . Un programme d'haplodiploïdisation peut être envisagé chez l'échalote.
\end{abstract}

Allium cepa L var aggregatum = échalote / gynogenèse / culture in vitro / bouton floral / haploïde

Summary - Production of gynogenetic plants by in vitro culture of flower buds in shallot (Allium cepa $L$ var aggregatum). Embryos of gynogenetic origin have been obtained by in vitro culture of flower buds from many shallot genotypes on basal B5 medium of Gamborg with high sucrose concentration, supplemented with 2,4-D and BAP. Embryo production started about 50 d after plating and was maximal between the 82nd and the 116th days. Whole flower buds and isolated ovaries gave similar results. The stage of flower buds toward anthesis and sub-culturing on the same medium about $40 \mathrm{~d}$ after plating did not affect the results. The number of embryos produced by 100 plated buds greatly varied according to the genotype (0-55). These numbers were clearly higher than those previously obtained in onions. The percentage of haploids in the surviving plants, 22 months after plating was $77.6 \%$. The use of doubled haploids in shallot breeding can now be proposed.

Allium cepa $L$ var aggregatum = shallot / gynogenesis / in vitro culture / flower bud / haploid

\section{INTRODUCTION}

L'utilisation de l'haplodiploïdisation en amélioration des plantes présente un intérêt évident, en particulier chez des espèces à cycle long. Cependant plusieurs conditions doivent être réa- lisées pour que celte méthode puisse être appliquée avec succès :

- production élevée de plantes haploïdes à partir d'une large gamme de génotypes ;

- possibilité de doublement du stock chromosomique ; 
- possibilité de contrôle du croisement entre génotypes homozygotes ;

- valeur élevée des combinaisons.

Diverses techniques de production d'haploïdes sont utilisées (Jensen, 1986) : recherche d'haploïdes spontanés, parthénogenèse induite par des croisements intraspécifiques, interspécifiques, voire intergénériques ou par utilisation de pollen inactivé, culture in vitro des gamétophytes mâle et / ou femelle.

Les échalotes cultivées en France comprennent 2 types : l'échalote de Jersey (Allium cepa L var aggregatum) considérée comme une forme d'oignon reproduite végétativement et l'échalote grise dont la position systématique est incertaine mais qui parait proche d'Allium oschaninii.

À notre connaissance, aucune tentative d'obtention de plantes haploïdes chez l'échalote n'a été signalée à ce jour. En revanche, chez l'oignon, des plantes haploïdes ont été obtenues par culture in vitro du gamétophyte femelle non fécondé (Muren, 1989 ; Campion et Aloni, 1990; Keller, 1990 a, b ; Smith et al, 1991 ; Campion et al, 1992) et in situ par utilisation de pollen inactivé par irradiation (Doré et Marie, 1993). Des embryons ont été obtenus en cultivant in vitro des ovules, des ovaires et des boutons floraux. Les milieux de culture les mieux adaptés ont en commun certaines caractéristiques : milieu de base B5 de Gamborg et al (1968) ou proche, concentration élevée en saccharose, présence d'acide 2,4-dichlorophénoxyacétique (2,4-D) et de 6-benzylaminopurine (BAP). La production d'embryons, très fortement dépendante du génotype, était le plus souvent inférieure à 3 embryons par 100 fleurs ou ovaires mis en culture. Une proportion parfois élevée de ces embryons ne s'est pas développée en plantules normales après repiquage in vitro. Le pourcentage d'individus haploïdes parmi les plantules obtenues varie de 70 (Muren, 1989) à 88 (Campion et al ,1992).

L'objet du présent travail était de mettre au point une technique efficace d'obtention d'embryons d'origine gynogénétique chez une série de génotypes d'échalote, de suivre ces embryons jusqu'à la plante au champ et de contrôler le niveau de ploïdie des plantes survivantes.

\section{MATÉRIEL ET MÉTHODES}

Le matériel végétal comprenait 4 clones de type Jersey («Mikor», Ho, H2, H3), 27 génotypes issus de 6 familles $(87.20,87.21,89.31,89.37,89.44,89.49)$ ayant toutes un ascendant d'origine tropicale $\mathrm{O} A \mathrm{x}$ Échalote Guadeloupe (Messiaen et al, 1993) et un clone florifère d'échalote grise. Les bulbes ont été plantés mi-novembre sous tunnel plastique non chauffé.

Les boutons floraux, prélevés à différents stades d'évolution, ont été désinfectés par un trempage de 15 min dans une solution d'eau de Javel à $12^{\circ}$ chlorométriques suivi de 3 rinçages à l'eau distillée stérilisée. Dans un essai préliminaire réalisé en 1990, le périanthe et les étamines ont été enlevés sur une partie des boutons floraux; par la suite, seuls des boutons floraux entiers ont été mis en culture (du 10/6 au 10/7/1991). Le milieu préconisé par Muren (1989) a été utilisé : B5 de Gamborg (Sigma G5893), 2,4-D $(9 \mu \mathrm{M})$, BAP $(6,5 \mu \mathrm{M})$, saccharose $(100 \mathrm{~g} / \mathrm{l})$, agent gélifiant (Danagel $8 \mathrm{~g} / \mathrm{l})$. Le $\mathrm{pH}$ était ajusté à 6,1-6,2 avant passage à l'autoclave à $115^{\circ} \mathrm{C}$ pendant $30 \mathrm{~min}$. Quinze fleurs de grosseur homogène ont été implantées par boîte de Pétri (diamètre de $90 \mathrm{~mm}$ ) contenant $20 \mathrm{ml}$ de milieu. Les boîtes scellées par du Parafilm ${ }^{\circledR}$ ont été placées dans une cellule éclairée $16 \mathrm{~h}$ par $24 \mathrm{~h}$ (35 $\mu \mathrm{mol} \mathrm{s} \mathrm{m}^{-1} \mathrm{~m}^{-2}$ fournies par des tubes fluorescents) à une température de $25^{\circ} \pm 2^{\circ} \mathrm{C}$. Cette température a été abaissée à $18^{\circ}-20^{\circ} \mathrm{C}$ une centaine de jours après la mise en culture. Quarante j environ après la mise en culture, $50 \%$ des explants ont été repiqués sur un milieu identique au milieu d'origine puis replacés dans les mêmes conditions.

Les structures embryonnaires qui sont apparues ont été repiquées en tubes $(160 \times 24 \mathrm{~mm})$ sur le milieu suivant : B5 de Gamborg (Sigma G 5893), acide indol3-butyrique $(0,5 \mu \mathrm{M})$, saccharose $(30 \mathrm{~g} / \mathrm{l})$ ), agent gélifiant (Danagel $8 \mathrm{~g} / \mathrm{l}), \mathrm{pH}$ ajusté à 6,1-6,2. Les tubes ont été placés à $18^{\circ}-20^{\circ} \mathrm{C}$ sous $16 \mathrm{~h}$ d'éclairement par $24 \mathrm{~h}$. Après enracinement et croissance foliaire, les plantules ont d'abord été repiquées en godets remplis de terreau puis transférées en pleine terre sous tunnel fin mars 1992. Les bulbes produits par ces plantes ont été récoltés en août, conservés en clayettes sous hangar et replantés au champ en décembre 1992. Le contrôle du niveau de ploïdie a été effectué sur les plantes-filles par dénombrement chromosomique sur pointes de racines (coloration de Feulgen) chez 40 plantes et par évaluation des teneurs en ADN des noyaux de fragments de feuilles par cytométrie en flux selon la technique décrite par Chauvin et al (1993), sur l'ensemble du matériel.

\section{RÉSULTATS}

Après la mise en culture on observe l'ouverture des fleurs et le grossissement des ovaires. Dans quelques cas, des structures vertes de type embryonnaire issues d'un ovule sortent des cavités ovariennes et peuvent s'organiser en plantules. Les sorties d'embryons débutent 50 à $60 \mathrm{j}$ après la mise en culture et se poursuivent jusqu'au $180^{\mathrm{e}}$ jour. Soixante-dix \% d'entre eux apparaissent entre le $82^{\mathrm{e}}$ et le $116^{\mathrm{e}}$ jour. 
L'essai préliminaire, mettant en comparaison des boutons floraux entiers d'une part et des ovaires sans périanthe ni étamines d'autre part, n'a pas montré de différence significative entre les 2 traitements (respectivement 45 embryons pour 1050 boutons et 15 embryons pour 408 ovaires isolés). Ce résultat nous a conduit à n'utiliser par la suite que des boutons floraux entiers, ce qui évite l'étape de la dissection.

Le stade d'évolution des boutons floraux a été estimé indirectement par la précocité d'ouverture des fleurs in vitro. L'analyse de l'influence de 3 stades d'évolution sur l'apparition d'embryons a été faite sur les 5 génotypes les plus réactifs ; elle a porté sur les ovules car certains explants ont produit plus d'un embryon (tableau I). Pour 4 d'entre eux, la production d'embryons est indépendante du stade d'évolution du bouton au moment du prélèvement (au seuil $5 \%$ de signification).

La formation d'un cal à la base des pièces florales est parfois observée; ce phénomène est nettement plus fréquent chez les boutons floraux jeunes (402 cals pour 2200 explants) que chez les boutons proches de l'anthèse (96 cals pour 2200 explants). Ces cals sont parfois organogènes.

Les explants repiqués sur le même milieu environ $40 \mathrm{j}$ après la mise en culture ne se comportent pas différemment de ceux maintenus sur le milieu d'origine (respectivement 372 embryons pour 3350 boutons floraux et 337 embryons pour 3310 boutons).
Le nombre d'embryons repiqués pour 100 fleurs implantées varie de 0 à 55 selon le génotype (tableau II). Sept génotypes sur les 32 étudiés n'ont formé aucun embryon, il s'agit de l'échalote grise, de Ho (type Jersey) et de 5 génotypes d'origine tropicale. Il existe des différences importantes de comportement entre génotypes à l'intérieur d'une famille et entre les familles (comparer par exemple 89.44 à 89.31 et à 89.37).

Les effectifs d'embryons et de plantes à différentes étapes sont portés sur le tableau II: Sur 865 embryons repiqués in vitro, seuls 541 $(62,5 \%)$ ont donné des plantules qui ont pu être sevrées en terreau. L'importance des pertes semble varier selon le génotype : les descendants de la famille 89.49 présentent des pertes plus élevées que ceux de la famille 89.44. Soixante-quinze \% des embryons non exploitables ont formé des racines, $45 \%$ sont albinos, $42 \%$ ont peu évolué après le repiquage en tube, enfin $12 \%$ sont anormaux (plantule hyperhydrique, croissance anormale, développement d'un cal).

De nouvelles pertes sont observées entre l'acclimatation et la maturité des plantes ; elles sont essentiellement dues à la disparition de plantules fragiles et chétives et à des attaques parasitaires précoces. Les plantes présentent une variabilité importante en ce qui concerne la vigueur, la précocité de bulbification, la maturité ; certaines d'entre elles ont fleuri. Les diminutions des effectifs entre juillet 1992 et décembre 1993 s'expliquent par les pertes rencontrées au cours

Tableau I. Influence du stade d'évolution de la fleur au moment du prélèvement sur la production d'embryons gynogénétiques chez 5 génotypes réactifs (ovule réactif = ovule produisant un embryon).

\begin{tabular}{|c|c|c|c|c|c|c|}
\hline Génotype & & $\begin{array}{l}\text { Anthèse } \\
\text { avant } 5 j\end{array}$ & $\begin{array}{l}\text { Anthèse } \\
\text { entre } 5 \text { et } 10 j\end{array}$ & $\begin{array}{l}\text { Anthèse } \\
\text { après } 10 j\end{array}$ & $x^{2}$ & $P$ \\
\hline 87.21 .1 & $\begin{array}{l}\text { Nombre d'ovules } \\
\% \text { d'ovules réactifs }\end{array}$ & $\begin{array}{l}720 \\
2,6\end{array}$ & $\begin{array}{l}720 \\
2,4\end{array}$ & $\begin{array}{l}720 \\
2,6\end{array}$ & 0,15 & 0,10 \\
\hline 89.44 .3 & $\begin{array}{l}\text { Nombre d'ovules } \\
\% \text { d'ovules réactifs }\end{array}$ & $\begin{array}{l}360 \\
4,2\end{array}$ & $\begin{array}{l}360 \\
3,1\end{array}$ & $\begin{array}{l}360 \\
3,6\end{array}$ & 0,64 & 0,25 \\
\hline 89.44 .4 & $\begin{array}{l}\text { Nombre d'ovules } \\
\% \text { d'ovules réactifs }\end{array}$ & $\begin{array}{l}630 \\
8,6\end{array}$ & $\begin{array}{l}630 \\
14,9\end{array}$ & $\begin{array}{l}630 \\
12,4\end{array}$ & 12,23 & $>0,99$ \\
\hline 89.44 .12 & $\begin{array}{l}\text { Nombre d'ovules } \\
\% \text { d'ovules réactifs }\end{array}$ & $\begin{array}{l}360 \\
5,6\end{array}$ & $\begin{array}{l}360 \\
5,0\end{array}$ & $\begin{array}{l}360 \\
6,7\end{array}$ & 0,96 & 0,35 \\
\hline 89.49 .4 & $\begin{array}{l}\text { Nombre d'ovules } \\
\% \text { d'ovules réactifs }\end{array}$ & $\begin{array}{l}270 \\
3,3\end{array}$ & $\begin{array}{l}270 \\
6,3\end{array}$ & $\begin{array}{l}270 \\
2,6\end{array}$ & 5,31 & 0,92 \\
\hline
\end{tabular}


Tableau II. Influence du génotype de la plante donneuse sur le nombre d'embryons repiqués, sevrés, présents en juillet 1992 et en décembre 1993 et sur le niveau de ploïdie des plantes suvivantes.

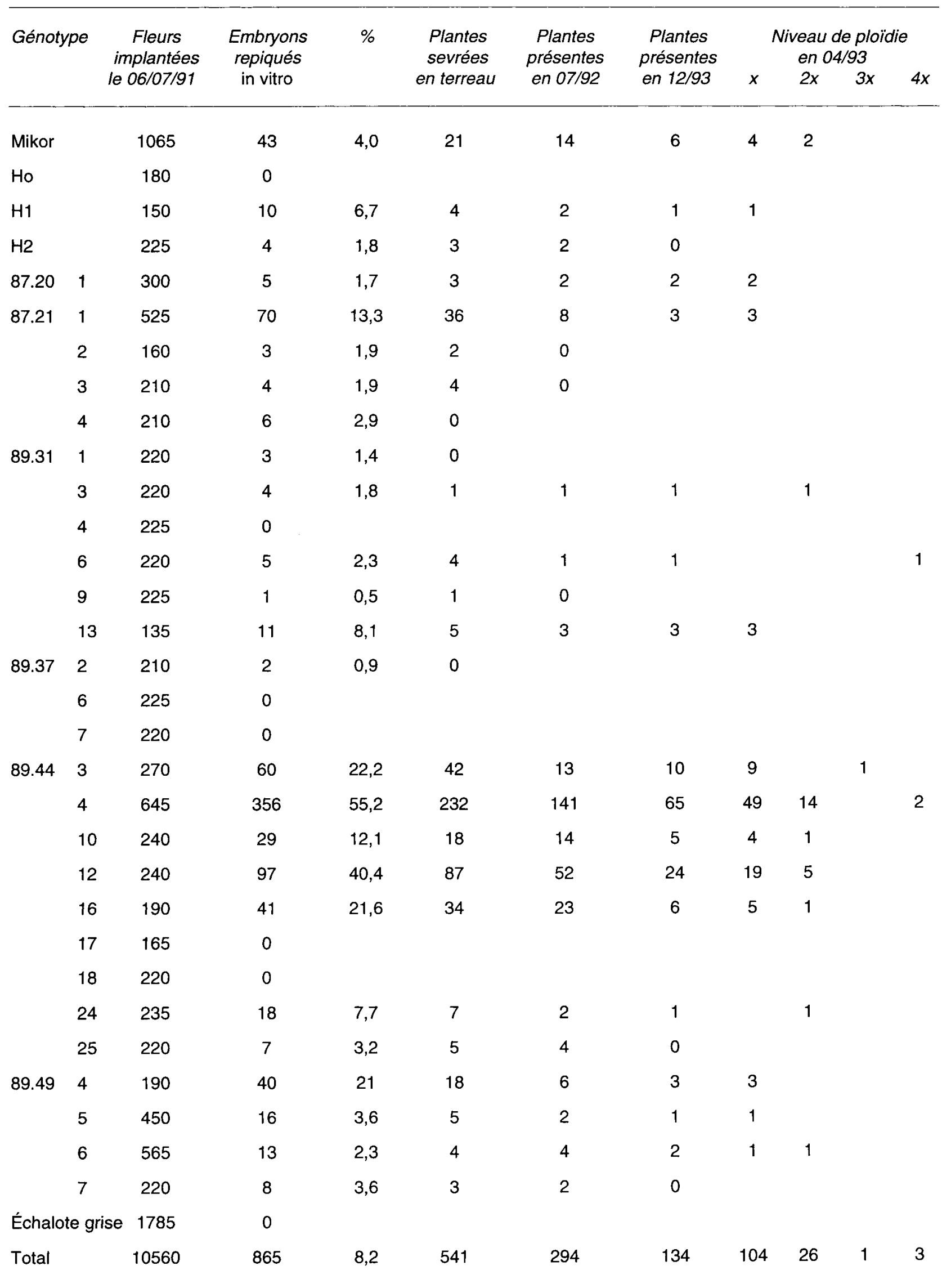


des 2 campagnes de conservation et durant la végétation au champ. Les conditions de conservation et de culture utilisées ont été celles appliquées en production commerciale ; elles n'étaient probablement pas les plus favorables pour les bulbes puis pour les plantes d'origine gynogénétique.

Les contrôles du niveau de ploïdie réalisés sur les plantes survivantes ont montré que $78 \%$ d'entre elles sont haploïdes, $19 \%$ diploïdes et $3 \%$ polyploïdes (tableau II). Les 2 techniques de contrôle appliquées à 40 plantes ont donné des résultats concordants.

\section{DISCUSSION}

L'obtention d'embryons gynogénétiques par culture in vitro de jeunes fleurs non pollinisées est possible chez certains génotypes d'échalote. Des pertes importantes ont été observées entre le repiquage et l'acclimatation puis en culture et durant la conservation des bulbes. La majorité des plantes survivantes sont haploïdes.

La production d'embryons a débuté 50 à 60 j après la mise en culture, elle était maximale entre le $82^{e}$ jour et le $116^{\mathrm{e}}$ jour. Chez l'oignon, Campion et al (1992) ont observé cette production maximale entre le $75^{\mathrm{e}}$ et le $95^{\mathrm{e}}$ jour. Tout comme ces auteurs nous avons observé que les embryons formés tardivement régénèrent moins de plantules normales que ceux formés tôt.

Les mises en culture in vitro avant pollinisation de jeunes boutons floraux d'une part, d'ovaires isolés après enlèvement du périanthe et des étamines d'autre part, ont donné des résultats équivalents. Guha et Johri (1966) avaient montré l'influence favorable de la présence du périanthe sur l'évolution des ovules d'Allium cepa $L$ in vitro. Le fait d'implanter des fleurs entières aurait pu présenter le risque d'une autopollinisation à l'intérieur des boîtes. En fait la déhiscence des anthères n'a pas été observée sous les conditions in vitro. La mise en culture de boutons floraux entiers est 3 fois plus rapide que celle d'ovaires isolés. Ces différentes observations nous ont conduit à n'utiliser ensuite comme explants que des boutons floraux entiers.

Le stade d'évolution du bouton floral au moment du prélèvement a peu influencé le potentiel de production d'embryons chez la plupart des génotypes. L'utilisation de boutons floraux trop jeunes est à déconseiller, en particulier en raison de leur propension à produire des cals à la base des pièces florales. Dans le cas de boutons floraux avancés, le développement des cals était rare et l'origine gynogénétique des embryons ne faisait pas de doute. Un repiquage sur le même milieu, effectué une quarantaine de jours après la mise en culture, n'a pas eu d'effet significatif sur la gynogenèse.

Dans les conditions expérimentales utilisées, le génotype de la plante donneuse a exercé une forte influence sur la production d'embryons gynogénétiques. Cet effet génotype a déjà été mentionné chez l'oignon (Muren, 1989 ; Keller 1990b, Smith et al, 1991 ; Campion et al, 1992). Il a été observé ici à l'intérieur d'une descendance comme entre descendances. Certains génotypes ont été totalement réfractaires : c'est en particulier le cas de l'échalote grise chez laquelle d'autres tentatives réalisées postérieurement et portant au total sur plus de 10000 fleurs et différents milieux se sont révélées infructueuses. Cette situation est peut être à rapprocher de la stérilité totale de cette échalote sous nos conditions de culture.

Les résultats obtenus chez les génotypes d'échalote les plus performants avec pour certains plus de 55 embryons pour 100 fleurs mises en culture, sont nettement supérieurs aux résultats les plus favorables rapportés chez l'oignon et qui varient de 2 à 9,9\% selon les auteurs (Muren, 1989 ; Keller, 1990b ; Smith et al, 1991 ; Campion et al, 1992). Les phases d'acclimatation puis de culture en pleine terre et de conservation des bülbes sous des conditions de production commerciale entraînent la disparition des plantes et bulbes les plus fragiles et les moins bien adaptés à ces conditions. Après 2 saisons de culture, $84,5 \%$ des embryons repiqués ont disparu et, parmi les 25 génotypes donneurs réactifs, 9 ne sont plus représentés. Dans une optique de création variétale, il sera indispensable d'utiliser une large gamme de génotypes donneurs pour espérer disposer d'une variabilité suffisante dans la population d'haploïdes doublés.

Le pourcentage de plantes haploïdes parmi les plantes survivantes est de 77,6 ; il est voisin de celui mentionné chez l'oignon, 70 et $88,3 \mathrm{chez}$ respectivement Muren (1989) et Campion et al (1992). L'état homozygote ou hétérozygote, et l'origine des individus diploïdes restent à préciser. Deux génotypes donneurs, 89-44-4 et 89-4412 , ont produit plusieurs plantes diploïdes ; ces dernières sont toutes différentes les unes des autres et différentes de la plante donneuse, ce qui exclut une régénération à partir de tissus maternels. On peut penser alors à un doublement spontané d'un embryon haploïde ; l'état homozygote pourra être vérifié par l'étude de la 
descendance d'autofécondation ou du croisement par une plante homozygote. Une autre possibilité de contrôle est l'étude électrophorétique de systèmes enzymatiques suffisamment polymorphes. Le développement à partir d'un gamète non réduit peut aussi expliquer l'état diploïde : les plantes peuvent alors être homozygotes ou hétérozygotes.

La première étape d'un programme d'haplodiploïdisation est donc réalisable chez l'échalote ; le problème du doublement du stock chromosomique des plantes haploïdes reste à résoudre.

\section{RÉFÉRENCES}

Campion B, Alloni C (1990) Induction of haploid plants in onion (Allium cepa $L$ ) by in vitro culture of unpollinated ovules. Plant Cell, Tissue and Organ Cult 20, 1-6

Campion B, Azzimonti MT, Vicini E, Schiari M, Falavigna A (1992) Advances in haploid plant induction in onion (Allium cepa $L$ ) through in vitro gynogenesis. Plant Sci 86, 97-104

Chauvin JE, Yang Q, Le Jeune B, Hervé Y (1993) Obtention d'embryons par culture d'anthères chez le chou-fleur et le brocoli et évaluation des potentialités du matériel obtenu pour la création variétale. agronomie 13, 579-590
Doré C, Marie F (1993) Production of gynogenetic plants of onion (Allium cepa L) after crossing with irradiated pollen. Plant Breed 111, 142-147

Gamborg O L, Miller R A, Ojima K (1968) Nutrient requirements of suspension culture of soybean roots cells. Expt Cell Res 50, 157-158

Guha S, Johri B M (1966) In vitro development of ovary and ovule of Allium cepa L. Phytomorphology $16,353-364$

Jensen $\mathrm{C} \mathrm{J} \mathrm{(1986)} \mathrm{Haploid} \mathrm{induction} \mathrm{and} \mathrm{production} \mathrm{in}$ crops plants. In : Genetic Manipulation in Plant Breeding (W Horn, CJ Jensen, W Odenbach, $O$ Schieder, eds), De Gruyter, Berlin, New York, 231256

Keller J (1990a) Results of anther and ovule culture in some species and hybrids in the genus Allium $\mathrm{L}$. Arch Züchtungsforsh 20, 189-197

Keller J (1990b) Culture of unpollinated ovules, ovaries and flower buds in some species of the genus Allium and haploid induction via gynogenesis in onion (Allium cepa L). Euphytica 47, 241-247

Messiaen CM, Cohat J, Leroux JP, Pichon M, Beriyes A (1993) Les Allium alimentaires reproduits par voie végétative. INRA, Paris, 139-163

Muren RC (1989) Haploid plant induction from unpollinated ovaries in onion. Hortsci 24, 833-834

Smith BM, Godwin RM, Harvey E, Werner CP (1991) Gynogenesis from whole flower buds in bulb onions (Allium cepa $L$ ) and leeks (Allium porrum L). J Genet Breed 45, 353-358 